\title{
Dermatoglyphs of Klinefelter's syndrome
}

\author{
HIROSHI SHIONO, JUN-ICHI KADOWAKI, HITOSHI TANDA, AND \\ MASAHIRO HIKITA
}

From the Department of Legal Medicine, Sapporo Medical College, Chuoko, Sapporo; the Department of Pediatrics, National Nishi-Sapporo Hospital, Nishiku, Sapporo; and the Department of Urology, Sapporo Medical College, Chuoku, Sapporo, Japan

SUMMARY The dermatoglyphs of 28 Japanese with Klinefelter's syndrome [24 XXY; 2 XXYY; 1 XXXY; 1 XXXXY] were compared with 544 male and 129 female controls.

These patients showed high frequencies of fingertip arches pattern, right third interdigital loops, right hypothenar patterns $\left(\mathrm{L}^{\mathrm{r}}\right)$ and line $C$ terminating 0 in the right hand.

The mean summed $a-b$ ridge count of Klinefelter's syndrome patients was significantly lower than that of the male controls. We suggest that an increase in the number of $\mathrm{X}$ or $\mathrm{Y}$ chromosomes decreased the $a-b$ ridge count in a similar way to the decrease in total finger ridge count.

Several studies on the dermatoglyphs in Klinefelter's syndrome have been reported (Penrose, 1963; Forbes, 1964; Uchida and Soltan, 1963; Holt, 1964, 1968; Cushman and Soltan, 1969). Penrose (1963) and Forbes (1964) found a low total ridge count and an increased number of arches on the fingers. On the other hand, Uchida and Soltan (1963) and Cushman and Soltan (1969) found no characteristic pattern in series of 14 and 55 patients, respectively.

\section{Subjects and methods}

Twenty-eight Japanese with Klinefelter's syndrome were studied. The age of the patients with Klinefelter's syndrome ranged from 12 to 67 years.

The chromosomal analyses were conducted by modifications of the method described by Moorhead et al. (1960).

The control group consisted of 544 male and 129 female students of Sapporo Medical College and Nurse Training School, aged 22 to 25 years. They were unrelated, all of Japanese origin, and apparently healthy.

Fingerprints were recorded by using the Hollister fingerprint method, and palm prints were recorded with an ink stamp pad.

\section{Results}

The clinical and chromosomal features of several patients in this series have already been published
(Takai et al., 1962, 1964, 1965; Shimamura and Hikita, 1965; Sasaki et al., 1967).

The sex-chromosome complements were: XXY ( 24 cases); XXYY ( 2 cases); XXXY (1 case); XXXXY (1 case).

\section{DIGITAL PATTERNS}

The percentage frequencies of whorls, ulnar and radial loops, and arches on all fingers in Klinefelter's syndrome and those of the male controls are shown in Table 1.

The following results were obtained.

(1) In general, the frequencies of the whorl patterns tended to increase as those of the ulnar and radial loop patterns decreased. The differences between the whorl pattern in Klinefelter's syndrome and those in the control males were not significant $\left(\chi^{2} 3 \cdot 7\right.$; df 1 ; $P<0.05$ ).

(2) The percentage frequencies of arches on all digits in Klinefelter's syndrome were statistically higher than those in the control group $\left(\chi^{2} 43.6\right.$; df 1 , $P<0.001$ ).

\section{PALMAR PATTERNS AND FLEXION}

The percentage frequencies of interdigital loops, hypothenar patterns, and thenar patterns of Klinefelter's syndrome patients and both control groups are shown in Tables 2 to 4 .

(3) The mean atd angle was $44.6^{\circ}$ on the left hand and $36.9^{\circ}$ on the right hand. There was no significant difference between patients and controls for the atd angle; (left: $\chi^{2} 0.5 \mathrm{df} 1$; right; $\chi^{2} 0.9 \mathrm{df} 1$ ). 
Table 1 Percentage frequencies of all digital patterns in Klinefelter's syndrome and in controls

\begin{tabular}{|c|c|c|c|c|c|c|c|}
\hline & \multicolumn{2}{|c|}{ Klinefelter's syndrome } & \multicolumn{4}{|l|}{ Controls } & $\stackrel{(D)}{\because}$ \\
\hline & \multirow{2}{*}{$\begin{array}{l}\text { Shiono (this report) } \\
\text { (28 cases) }\end{array}$} & \multirow{2}{*}{$\begin{array}{l}\text { Holt }(1968) \\
(48 \text { cases })\end{array}$} & \multicolumn{2}{|c|}{ Shiono (this report) } & \multicolumn{2}{|c|}{ Holt (1968) } & (5) \\
\hline & & & 544 Males & 129 Females & Males & Females & \\
\hline Whorl & 53.4 & $24 \cdot 5$ & $47 \cdot 7$ & 40.0 & $27 \cdot 6$ & $24 \cdot 4$ & $\overline{\bar{\omega}}$ \\
\hline Ulnar loop & $39 \cdot 3$ & $61 \cdot 3$ & $47 \cdot 2$ & $54 \cdot 5$ & $62 \cdot 4$ & 63.6 & \\
\hline Radial loop & $1 \cdot 1$ & $5 \cdot 8$ & $3 \cdot 3$ & 3.4 & $6 \cdot 2$ & 5.6 & $\mathbb{D}$ \\
\hline Arch & $6 \cdot 1$ & $7 \cdot 5$ & $1 \cdot 8$ & $2 \cdot 1$ & $3 \cdot \overline{8}$ & 6.4 & \\
\hline
\end{tabular}

Table 2 Percentage frequencies of true hypothenar patterns $\left(L^{r}, A^{u} / L^{u}, A^{u} / L^{r}\right)$ in Klinefelter's syndrome and in controls

\begin{tabular}{|c|c|c|c|c|c|c|}
\hline \multirow[t]{2}{*}{ Hypothenar patterns } & \multicolumn{2}{|l|}{$L^{\mathbf{r}}$} & \multicolumn{2}{|c|}{$A^{\mathrm{u}} / L^{\mathrm{u}}$} & \multicolumn{2}{|c|}{$A^{\mathrm{u}} / L^{\mathbf{r}}$} \\
\hline & $L$ & $\boldsymbol{R}$ & $L$ & $\boldsymbol{R}$ & $L$ & $\boldsymbol{R}$ \\
\hline $\begin{array}{l}\text { Klinefelter's syndrome } \\
28 \text { cases) } \\
544 \text { Male controls } \\
129 \text { Female controls }\end{array}$ & $\begin{array}{l}21 \cdot 4 \\
18 \cdot 9 \\
16 \cdot 2\end{array}$ & $\begin{array}{l}32.1 \\
15 \cdot 5 \\
13 \cdot 2\end{array}$ & $\begin{array}{l}3 \cdot 6 \\
0 \cdot 3 \\
0 \cdot 1\end{array}$ & $\begin{array}{l}0 \cdot 0 \\
0 \cdot 5 \\
0 \cdot 1\end{array}$ & $\begin{array}{l}0.0 \\
0.0 \\
0.0\end{array}$ & $\begin{array}{l}3 \cdot 6 \\
0 \cdot 2 \\
0 \cdot 1\end{array}$ \\
\hline
\end{tabular}

L, Left, R, Right.

(4) The frequencies of true hypothenar patterns $\left(L^{r}, A^{u} / L^{u}, A^{u} / L^{r}\right)$ in Klinefelter's syndrome and male controls are shown in Table 2. The percentage frequency of right hypothenar patterns $\left(L^{r}\right)$ was statistically significant $\left[\chi^{2} 5 \cdot 2976\right.$, df $1,0.25<\mathrm{P}<$ 0.01 .

A hypothenar pattern accompanied by an ulnar triradius was observed on the right palm of only one patient with XXYY.

(5) The second, third, and fourth interdigital loops of patients with Klinefelter's syndrome are shown in Table 3. Patients with Klinefelter's syndrome had more third interdigital loops than male controls, this difference being significant on the right $\left(\chi^{2} 4 \cdot 9\right.$, df 1 , $P<0.01)$ but not significant on the left $\left(\chi^{2} 0.6\right.$, df 1$)$.

(6) The frequencies of the line $\mathrm{C}$ terminating in the position 0 were observed in $7 \cdot 1 \%$ of the patients' left hands and in $17.9 \%$ of their right hands. In the male controls, the frequencies were 5.8 and $3.2 \%$, respectively (Table 4).

The difference between the percentage frequencies of the line $\mathrm{C}$ terminating in the position 0 of the
Table 3 Percentage frequencies of thenar, second, third, and fourth interdigital loop patterns in Klinefelter's syndrome and in controls

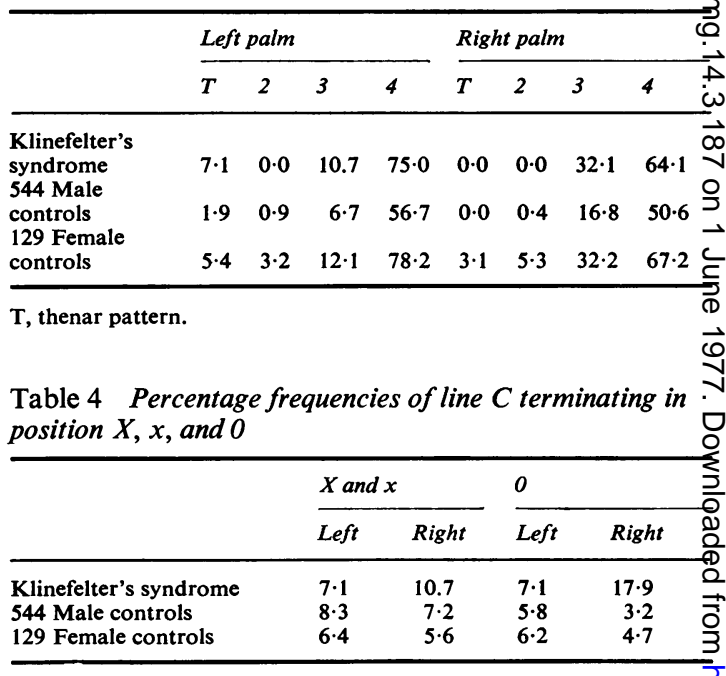

$\mathrm{X}$, Main line in which the proximal radiant can be traced for a show distance.

$\mathbf{x}$, No main line, though the triradius is present.

0 , Lack of the triradius

right hand in Klinefelter's syndrome and those im male controls was statistically significant $\left[\chi^{2} \quad 12 \cdot 9\right.$ @ df; 1 P $<0.001$ ].

(7) The mean total ridge count and the palmar $a-\not$ ridge count of Klinefelter's syndrome were shown in Table 5. The mean total ridge count of the XX patients was very similar to that of the females

Table 5 Means of total ridge counts, $a-b$ ridge counts and atd angles

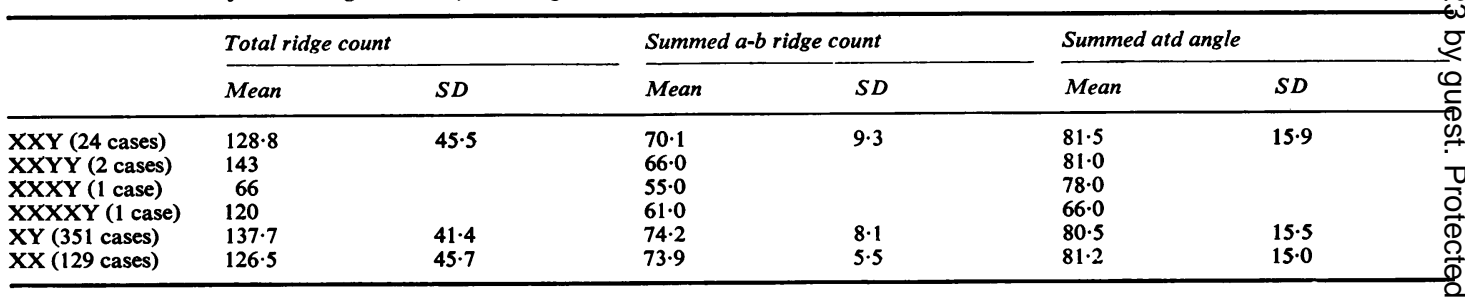


controls. The mean summed $a-b$ ridge count of the Klinefelter's syndrome patients was lower than that of the male controls.

\section{Discussion}

In their reports on Klinefelter's syndrome, Penrose (1963) and Forbes (1964) noted a slight general tendency towards pattern with low counts and a frequent occurrence of arches on the fingers. But, Uchida and Soltan (1963) and Cushman and Soltan (1969) disagreed with the above findings, and these patients with Klinefelter's syndrome failed to produce anything characteristic.

In the present survey, the presence of arch patterns was a characteristic dermatoglyphic feature of this syndrome. The frequency of whorl patterns on all digits tended to be increased, though the incidence of whorl pattern was found to be higher in Japanese controls than Caucasian controls.

The present two XXYY patients showed no arch patterns, though the arch pattern amounted to $14 \%$ in the $20 \mathrm{XXYY}$ patients reported by Uchida et al. (1964), Alter et al. (1966), and Shiono (1969). But, a hypothenar pattern accompanied by an ulnar triradius in patients with XXYY was the most characteristic feature (Uchida et al., 1964; Alter et al., 1966; Shiono, 1969). The presence of this pattern might, therefore, be helpful in distingushing the XXYY karyotype from the other types of Klinefelter's syndrome. The hypothenar pattern with ulnar triradius was observed on the right hand of only 1 patient of ours with XXYY.

As regards total ridge count, Penrose (1967) emphasized that an increase of sex chromosome diminished total ridge count, and the effect of an $\mathrm{X}$ chromosome in reducing fingerprint pattern size can be seen to be much greater than the effect of a $\mathrm{Y}$ chromosome. The mean total ridge count of the present XXY Klinefelter's syndrome is almost the same as the mean count of the female Japanese population, despite the increased frequency of whorl patterns. However, the mean summed $a-b$ ridge count in 28 Klinefelter's syndrome is lower than that of the male controls, as previously reported (Shiono and Kadowaki, 1971; Shiono et al., 1975). Since the mean summed $a-b$ ridge count of 28 patients with Klinefelter's syndrome is lower than that of the control group of either sex, we suggest that the summed $a-b$ ridge count is reduced by an increase in the number $\mathrm{X}$ or $\mathrm{Y}$ chromosomes. As suggested by Holt (1968), in order to supplement the information now available on the relations between sex chromosomes and the mean summed $a-b$ ridge count, further patients with aneuploidy of the sex chromosomes should be studied.

We are indebted to Drs T. Nakao, E. Kumamoto, and S. Yasoshima of Sapporo Medical College for their helpful suggestions in preparing this paper.

\section{References}

Alter, M. G., Gorlin, R., Yunis, J., Peagler, F., and Bruhl, H. (1966). Dermatoglyphics in XXYY Klinefelter's syndrome. American Journal of Human Genetics, 18, 507-513.

Cushman, C. J., and Soltan, H. C. (1969) Dermatoglyphics in Klinefelter's syndrome (47 XXY). Human Heredity, 19, 641-653.

Forbes, A. P. (1964) Fingerprints and palmprints (dermatoglyphics) and palmar-flexion creases in gonadal dysgenesis, pseudohypoparathyroidism and Klinefelter's syndrome. New England Journal of Medicine, 270, 1268-1277.

Holt, S. B. (1964). The role of dermatoglyphics in medical biology. Medical World (London), 101, 112-125.

Holt, S. B. (1968). The Genetics of Dermal Ridges. Charles C. Thomas, Springfield, lllinois.

Moorhead, P. S., Nowell, P. S., Batipps, D. M., and Hungerford, D. A. (1960). Chromosome preparations leucocytes cultured from human peripheral blood. Experimental Cell Research 20, 613-616.

Penrose, L. S. (1963). Fingerprints, palms and chromosomes. Nature, 197, 933-938.

Penrose, L. S. (1967). Finger-print pattern and the sex chromosome. Lancet, 1, 238-240.

Sasaki, T., Hikita, M., and Sugawara, G. (1967) Six additional cases of abnormal sex chromosome constitutions. Sapporo Medical Journal, 32, 347-351.

Shimamura, S., and Hikita, M. (1965). Two additional cases of Klinefelter's syndrome with special reference to chromosome examination by short-term culture of peripheral blood. Sapporo Medical Journal, 28, 74-79.

Shiono, H. (1969). Dermatoglyphics of XXYY Klinefelter's syndrome. Tohoku Journal of Experimental Medicine, 98, 1-6.

Shiono, H., and Kadowaki, J. (1971). The palmar a-b ridge count in Japanese: normal population, Down's syndrome and Klinefelter's syndrome. Human Biology, 43, 288-294.

Shiono, H., Kadowaki, J., and Tanda, H. (1975). The palmar a-b ridge count and sex chromosomes. Human Biology, 47, 505-509.

Takai, S., Morita, T., Shimamura, S., and Hikita, M. (1964). Abnormal sex chromosome constitution. Sapporo Medical Journal, 26, 226-244.

Takai, S., Morita, T., Shimamura, S., Tonomura, A., and Matsunaga, E. (1962). Clinical and chromosomal features in two cases of Klinefelter's syndrome. Journal of Urology, 88, 533-537.

Takai, S., Sasaki, T., and Hikita, M. (1965). XXYY Klinefelter's syndrome. Japanese Journal of Urology, 56, 616-621.

Uchida, I. A., and Soltan, H. C. (1963). Evaluation of dermatoglyphics in medical genetics. Pediatric Clinics of North America, 10, 409-422.

Uchida, I. A., Miller, J. R., and Soltan, H. C. (1964). Dermatoglyphics associated with the XXYY chromosome complement. American Journal of Human Genetics, 16, 284-291.

Requests for reprints to Dr Hiroshi Shiono, Department of Legal Medicine, Sapporo Medical College, S-1. $\overline{\mathrm{W}}-17$, Chuoko, Sapporo, Japan. 